\title{
TREE-RING CHRONOLOGIES OF DOWNY OAK (QUERCUS PUBESCENS), PEDUNCULATE OAK (Q. ROBUR) AND SESSILE OAK (Q. PETRAEA) IN THE BIELINEK NATURE RESERVE: COMPARISON OF THE CLIMATIC DETERMINANTS OF TREE-RING WIDTH
}

\author{
ANNA CEDRO \\ Department of Climatology and Marine Meteorology, \\ Institute of Marine Sciences, University of Szczecin, \\ Waska 13, 71-415 Szczecin
}

\begin{abstract}
In 2004-2006, 50 trees of downy oak (Quercus pubescens), pedunculate oak (Q. robur) and sessile oak $(Q$. petraea) were sampled in the Bielinek Nature Reserve. The following chronologies were established from their tree-ring series: OMS of 212 years (1793-2004) for downy oaks well as D10 of 183 years (1817-1999) and D13 of 211 years (1789-1999) for the two indigenous oak species pedunculate and sessile oak, respectively. These chronologies were used for signature years and response function analyses. All three chronologies were highly similar, which points to identical responses to the ambient meteorological conditions. The radial increment of downy oak depends primarily on the amount of precipitation. A high annual sum of precipitation, copious rain in springsummer in particular, results in wide tree rings. Precipitation in form of rain and snow in winter, too, enhance tree growth by raising the groundwater level and improving the water supply in the habitat during the subsequent spring. Droughts in spring and summer, coupled with high air temperature, result in narrow rings. The tree-ring width/climate relationships at the two indigenous oak species are very similar to those of downy oak. Responses are, however, more distinct and with a higher statistical significance.
\end{abstract}

Keywords: dendroclimatology, Quercus pubescens, $Q$. robur and Q. petraea, Bielinek Nature Reserve

\section{INTRODUCTION}

The Bielinek Nature Reserve is unique in Poland. The communities of xenothermic swards and thermophilous oak woods, along with rare plant species, have no equivalent in the country. The Reserve was established in 1927 under the name "Naturschutzgebiet Bellinchen a. d. Oder" [Odra Slopes near Bielinek] and later maintained by the Polish authorities. Since 1957, the Reserve has been featuring on the map of protected areas of Poland as a forest-steppe nature reserve (Ciaciura, 1997a, b; Sukopp, 1997; Rezerwat..., 2000).

The Reserve is located in the westernmost area of Poland. It covers steep (grading up to $50^{\circ}$ ) slopes of the

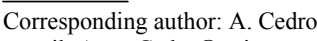

e-mail: Anna.Cedro@univ.szczecin.pl

ISSN 1897-1695 (online) C 2007 GADAM Centre,

Institute of Physics, Silesian University of Technology.

All rights reserved.
Odra valley facing south and south-west and rising to 70 $\mathrm{m}$ altitude. The slopes, incised by 12 gullies, support a high diversity of relief, lithological, hydrological conditions and microclimate, thus constituting a mosaic of habitats and plant communities.

The microclimatic conditions were studied by Brzoska in 1930-1932 (cf. Celiński and Filipek, 1958; Rezerwat... 2000). He reported large differences in meteorological parameters between sun-bathed slopes and shaded gullies. The maximum and minimum temperature differences between these two habitats may reach 16 and $7^{\circ} \mathrm{C}$, respectively; the daily temperature amplitude on sunny slopes and in shaded gullies is 27 and $13^{\circ} \mathrm{C}$, respectively. These differences are caused by the strong heating of the S- and SW-facing slopes during sunny days, followed by a high nocturnal heat radiation. The high air temperatures are associated with a low air humidity and high evapotranspiration. On a sunny day, the air 


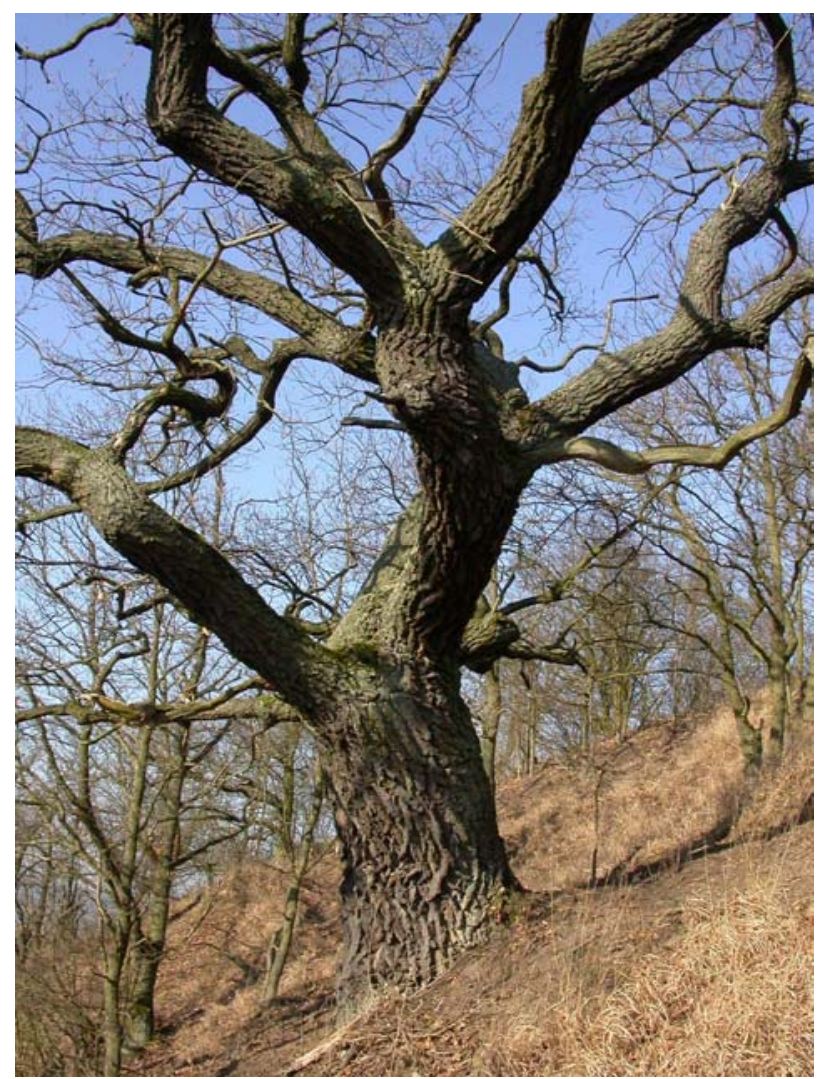

Fig. 1. A downy oak in the Bielinek reserve.

humidity on the slopes may drop below 30\%, while evapotranspiration may increase 8 -fold as compared to a shaded gully (cf. Celiński and Filipek, 1958, p. 28). This high microclimatic variability results in a close coupling between the slope exposure and type of plant communities. The sunny south-facing slopes are occupied by xenothermic vegetation containing sub-Mediterranean plant species, while the shaded gullies nearby support elm-ash woods.

The best-known and most valuable among the floristic peculiarities of the Reserve is the downy oak (Quercus pubescens Willd.). The Reserve is the only Polish site of this species and marks its north-easternmost occurrence boundary. A further, island-like occurrence is located 300 $\mathrm{km}$ south, near Jena - Germany, on the slopes of Mount Kunitzberg. The northern continous boundary of downy oak runs in Lorraine, Alsace, south Tirol, Slovenske Rudohorie in Slovakia, and northern Moldavia in Roumania (Sukopp, 1997; Rezerwat..., 2000).

Individuals of downy oak in the Reserve have grown to a height of 20-24 $\mathrm{m}$ and a circumference of 2-3 m (Boratyński, 1994 and 1995). The low-set canopy is very extensive (Fig. 1); the bark is ash-grey and finely and shallowly cracked. The leaves vary in size and shape; they are usually elliptic or inversely egg-shaped, and the top lobe is shorter than that of the indigenous oaks (Boratyński, 1994 and 1995). The trunks and leaves of oneyear-old trees are strongly hirsute in early spring (Fig. 2).

The downy oak population in the Reserve is estimated to about 1900 individuals most of which are not particularly tall (up to $12 \mathrm{~m}$ in height and $75 \mathrm{~cm}$ in trunk circumference measured at the height of $1.3 \mathrm{~m}$ ) (Ciaciura,

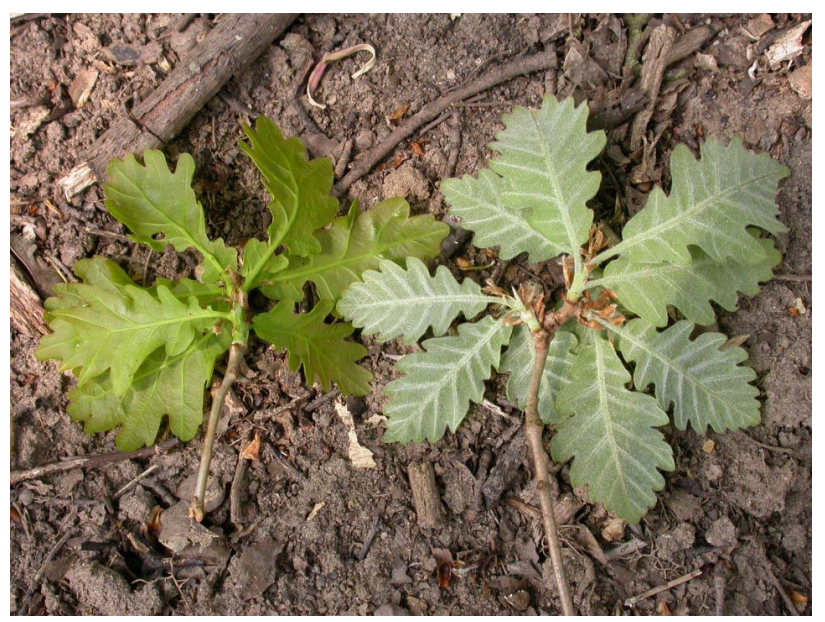

Fig. 2. Leaves of downy oak (right) and of indigenous oak species (left) in early May.
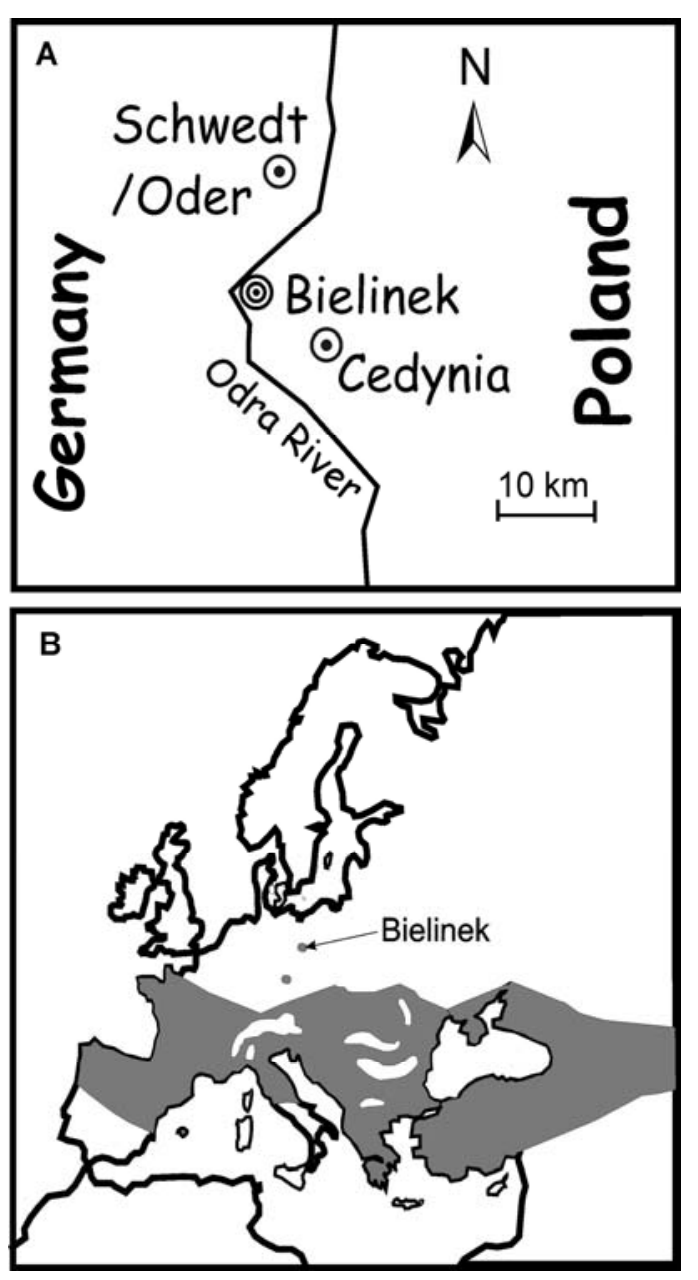

Fig. 3. Location of the study area. A, central part of the Bielinek reserve: $52^{\circ} 55^{\prime} 25^{\prime \prime} N$; $14^{\circ} 10^{\prime} 30^{\prime \prime} E$ (Rezerwat..., 2000); B, geographical range of Quercus pubescens in Europe.

1997b). The leaf morphometry and other diagnostic characters of the species indicate a high proportion of hybrids in the populations. Downy oak is the closest relative of sessile oak ( $Q$. petraea) with which it most frequently hybridises; however, hybrids of downy oak with pedun- 
Table 1. Statistical data for the tree-ring measurements and for the index chronologies of three oak species.

\begin{tabular}{|c|c|c|c|c|c|c|c|c|c|c|c|}
\hline \multirow{2}{*}{$\begin{array}{l}\text { Labora- } \\
\text { tory code }\end{array}$} & \multirow{2}{*}{$\begin{array}{l}\text { No. of } \\
\text { years }\end{array}$} & \multirow[b]{2}{*}{ Time span } & \multirow{2}{*}{$\begin{array}{c}\text { No. of } \\
\text { samples }\end{array}$} & \multirow{2}{*}{$\begin{array}{l}\text { Mean } \\
\text { width ring } \\
\quad(\mathrm{mm})\end{array}$} & \multirow{2}{*}{$\begin{array}{c}\text { Std. } \\
\text { Deviation } \\
(\mathrm{mm})\end{array}$} & \multirow{2}{*}{$\begin{array}{c}\text { Mean } \\
\text { sensitivity }\end{array}$} & \multirow{2}{*}{$\begin{array}{c}1^{\text {st }} \text { order } \\
\text { autocorrela- } \\
\text { tion }\end{array}$} & \multicolumn{4}{|c|}{ Index chronology } \\
\hline & & & & & & & & Median & $\begin{array}{l}\text { Mean sensi- } \\
\text { tivity }\end{array}$ & $\begin{array}{l}\text { Std. Devia- } \\
\text { tion }\end{array}$ & $\begin{array}{c}1^{\text {st }} \text { order auto- } \\
\text { correlation }\end{array}$ \\
\hline OMS & 212 & $1793-2004$ & 16 & 1.09 & 0.41 & 0.27 & 0.51 & 0.97 & 0.26 & 0.22 & 0.08 \\
\hline D10 & 183 & $1817-1999$ & 15 & 1.48 & 0.58 & 0.29 & 0.50 & 0.97 & 0.25 & 0.24 & 0.02 \\
\hline D13 & 211 & $1789-1999$ & 11 & 1.20 & 0.49 & 0.26 & 0.54 & 0.98 & 0.19 & 0.17 & -0.01 \\
\hline
\end{tabular}

culate oak ( $Q$. robur) and with $Q$. xrosacea are encountered as well (Staszkiewicz, 1977).

As indicated by its range, downy oak is physiologically well-adapted to drought conditions by a deep rooting system, xeromorphic leaves, osmotic adjustment, and stomatal closure during droughts (Weber et al., 2005).

The present study is aimed at (1) constructing a downy oak tree-ring chronology, (2) correlate it with the tree-ring chronologies of pedunculate and sessile oak, (3) investigating the effects of climate on these three oak species and comparing their tree-ring width/climate relationships.

\section{METHODS}

Field studies were carried out in 2004-2006 in the forest-steppe Bielinek Nature Reserve managed by the Regional Directorate of State Forests in Szczecin. Due to a high proportion of hybrids in the downy oak population, the plots and trees to be examined were selected after consultations with botanists and foresters, and after reference to previous studies which involved, among others, identification of individuals representing the typical Quercus pubescens. A total of three plots were studied: two of them supported the indigenous oak species ( $Q$. robur and $Q$. petraea) and one contained downy oak (Q. pubescens Willd.). A total of 50 trees were sampled by coring with 40 and $80 \mathrm{~cm}$ long Pressler borers. The cores were taken from two sides of the trunk to eliminate slope-related influences, at the height of $130 \mathrm{~cm}$; the trunk circumference was measured at this height as well. The bore holes were protected by wooden pegs and treated with a fungi- and bacteriocide (Lac-Balsam).

The tree-ring widths were measured using a special equipment coupled with the DendroMeter software (Mindur, 2000). All measurements, taken to $0.01 \mathrm{~mm}$, were performed twice from the part closest to the pith towards the bark. The occurrence of very narrow rings and of very wide or variable latewood was recorded, as was the number of rings in the sapwood. When the relevant statistics (linear correlation coefficient $\mathrm{k}$, t statistics and the coefficient of convergence GI) reached high values and the dendrochronological curves, constructed using the TRRAD module of the TREE RINGS computer package (Krawczyk, 1995; Krawczyk and Krapiec, 1995; Walanus, 2001) were concordant, the two measurements were averaged to obtain a tree-ring width series for a tree. Subsequently, local chronologies were assembled using the classical dendrochronological technique and tested with the COFECHA software (DPL program package, Holmes, 1983 and 1994). These local chronologies served as a basis for the analyses of signature years and response functions.

A signature year is a year in which the tree-ring width in most trees of a population is clearly wider or narrower than in previous and subsequent years (Huber and GiertzSiebenlist, 1969, cf. Kaennel and Schweingruber, 1995). Signature years are important in dendrochronological dating as well as in identification and elimination of errors in individual samples. Anomalies in the tree-ring curves appear in years with favourable or detrimental environmental factors, among which meteorological conditions are most important and most variable. The signature year analysis was carried out using the TCS software (Walanus, 2002); signature years were identified from at least 10 trees, and the minimum convergence threshold was set at $90 \%$.

In addition, relationships between climate and treering width were explored using the response function analysis (Fritts, 1976; Fritts and Xiangding, 1986; Blasing et al., 1984; Cook and Kairiukstis, 1990; Zielski and Krapiec, 2004). The response functions were calculated with the aid of the DPL program package (RESPO module, Holmes 1983 and 1994). The technique involves multiple regression analysis in which the mean monthly air temperature and monthly sum of precipitation are the independent variables. RESPO calculates coefficients of linear correlation $(\mathrm{k})$ and multiple regression $(\mathrm{r})$ as well as the multiple regression coefficient of determination $\left(r^{2}\right)$. The response function analysis was applied to follow the effects of climatic factors on the tree ring sequences in a 16-month period (from June of the year preceding the increment to September of the current growing year) over 57 years from 1948-2004. The study made use of climatic data collected by the nearest meteorological stations (Gorzów Wlkp. and Szczecin-Dąbie). Positive values of the linear correlation $(\mathrm{k})$ and multiple regression coefficient $(r)$ express a simultaneous increase of tree-ring width and the meteorological parameter. Negative values evidence a converse effect of a meteorological component on the tree-ring width. The value of $\mathrm{r}^{2}$ expresses the strength of the relationship between the climatic components and the tree-ring width.

\section{RESULTS}

\section{Chronologies}

The chronology for downy oak (OMS) was produced by combining 16 tree-ring series and consists of 212 rings (1793-2004; Fig. 4); the mean ring width is $1.09 \mathrm{~mm}$. The indigenous oak species produced two chronologies, denoted D10 and D13; D10 spans 183 years (1817-1999), while D13 spans 211 years (1789-1999; Fig. 5). The 


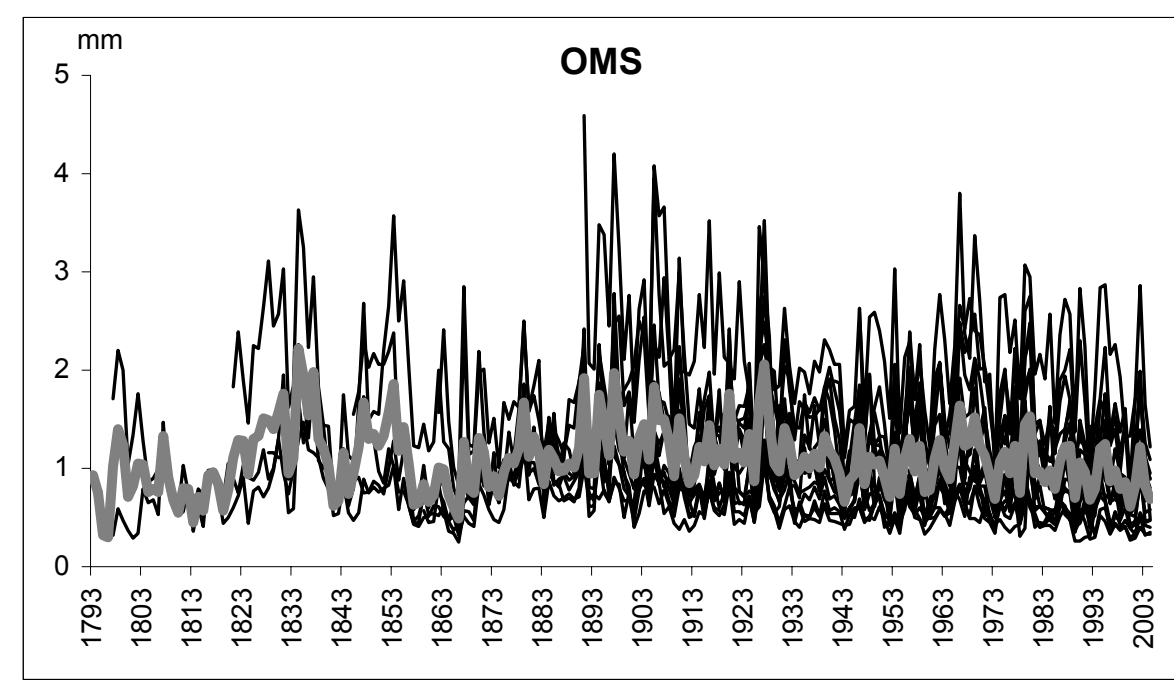

Fig. 4. Tree-ring series of 16 downy oaks (black lines) and resulting local chronology (grey line).

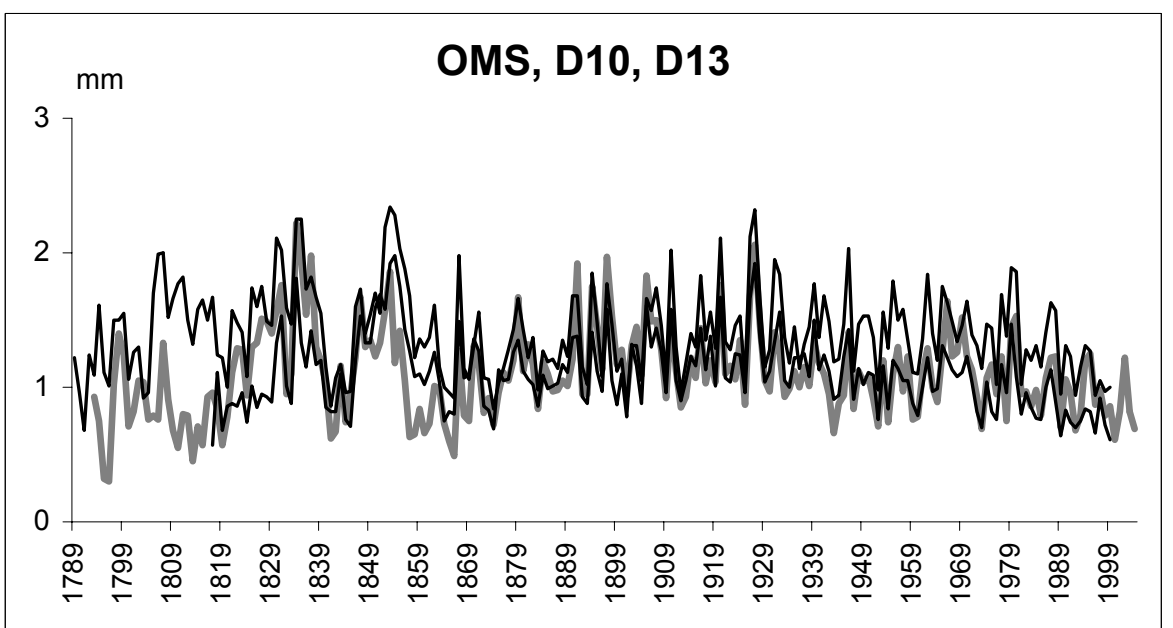

Fig. 5. Chronologies of downy oak (OMS, grey line) and the two native oak species (D10 and D13, black lines).

mean ring width in D10 and D13 is 1.48 and $1.2 \mathrm{~mm}$, respectively (Cedro, 2004 and Cedro, in press; Table 1). The OMS, D10 and D13 chronologies show a very high agreement between each other and high values of the test statistics (t from 11-20 and GI from 77-79\%). These values represent the upper part of the range found in Western Pomerania oak populations (Cedro, 2004).

\section{Signature years}

The local chronologies served as a basis for an analysis of signature years. For downy oak 55 signature years with an identical growth trend in at least $90 \%$ of the trees were identified ( 25 years with positive and 30 with negative trends; Table 2). Positive signature years were associated with a high annual sum of precipitation, copious precipitation in autumn-winter (prior to growth), and primarily - with higher - than - average precipitation in spring-summer (May-July).

Let us consider the year 1965 as an example. The annual sum of precipitation was higher than the multiannual average (Pma) both in Szczecin (1965 precipitation $=569 \mathrm{~mm}$, Pma=532 $\mathrm{mm}$ ) and in Gorzów (625 versus $541 \mathrm{~mm}$ ); May and July of that year, too, showed high sums of precipitation. The mean annual temperature was lower than the multi-annual mean (Tma) (1965 in Szczecin $=7.5^{\circ} \mathrm{C}$; $\mathrm{Tma}=8.5^{\circ} \mathrm{C} ; 1965$ in Gorzów $=7.3^{\circ} \mathrm{C}$; $\mathrm{Tma}=8.4^{\circ} \mathrm{C}$ ); summer temperatures, too, was lower than the multi-annual mean.

Negative signature years occurred when the annual sum of precipitation was lower than the multi-annual mean and/or featured droughts and high summer temperatures. The year 1989 is taken as, exceptionally dry and warm. The annual sums of precipitation in Szczecin and Gorzów were 421 and $397 \mathrm{~mm}$, respectively; in winter and spring (particularly in May precipitation was low), while precipitation in summer was at or below the multiannual mean. The mean annual temperature was very high; it was the warmest year within the period analysed (Szczecin: $\mathrm{t}=10.1^{\circ} \mathrm{C}$; Gorzów: $\mathrm{t}=9.9^{\circ} \mathrm{C}$ ); the winter-spring period was very warm and the summer very hot.

Similar relationships between signature years and climate were revealed for the indigenous oak species (Cedro, 2004). Depressed growth was primarily associated with annual of precipitation lower than the multiannual mean and with droughts in summer, while positive trends reflected sufficient water supply in the habitat, particularly in summer. Like for downy oak, an additional factor limiting tree-ring width of the indigenous oak spe- 


\begin{tabular}{|c|c|c|c|}
\hline YEAR & OMS & D10 & D13 \\
\hline 1884 & & + & + \\
\hline 1885 & & & - \\
\hline 1890 & & + & + \\
\hline 1892 & & - & - \\
\hline 1894 & + & + & + \\
\hline 1895 & - & & - \\
\hline 1896 & - & - & \\
\hline 1897 & + & + & + \\
\hline 1898 & - & & - \\
\hline 1899 & - & & \\
\hline 1901 & - & - & \\
\hline 1902 & + & & + \\
\hline 1903 & & & \\
\hline 1904 & - & - & - \\
\hline 1905 & + & + & + \\
\hline 1906 & - & & - \\
\hline 1909 & - & - & \\
\hline 1910 & + & + & + \\
\hline 1911 & - & - & - \\
\hline 1912 & - & - & - \\
\hline 1913 & & + & \\
\hline 1914 & + & & \\
\hline 1916 & + & + & + \\
\hline 1917 & - & - & - \\
\hline 1918 & & & + \\
\hline 1919 & & & - \\
\hline 1920 & + & + & + \\
\hline 1921 & - & - & - \\
\hline 1924 & + & & \\
\hline 1925 & - & - & \\
\hline 1926 & + & + & + \\
\hline 1927 & + & & + \\
\hline 1928 & - & & - \\
\hline 1929 & - & - & - \\
\hline 1931 & + & + & + \\
\hline 1932 & & & + \\
\hline 1933 & - & - & - \\
\hline & & & \\
\hline 1903 \\
\hline 1906
\end{tabular}

\begin{tabular}{|c|c|c|c|}
\hline YEAR & OMS & D10 & D13 \\
\hline 1934 & & & \\
\hline 1935 & & & + \\
\hline 1939 & + & & + \\
\hline 1940 & & & - \\
\hline 1943 & - & & \\
\hline 1944 & + & & \\
\hline 1945 & & & \\
\hline 1946 & + & & \\
\hline 1947 & - & & - \\
\hline 1952 & & & - \\
\hline 1953 & + & & + \\
\hline 1954 & - & & - \\
\hline 1955 & + & & + \\
\hline 1957 & - & & \\
\hline 1959 & - & & \\
\hline 1962 & + & & + \\
\hline 1963 & - & & - \\
\hline 1965 & + & & \\
\hline 1967 & - & & \\
\hline 1970 & - & & \\
\hline 1973 & - & & \\
\hline 1974 & + & & \\
\hline 1977 & & + & + \\
\hline 1978 & - & & \\
\hline 1979 & + & & + \\
\hline 1980 & & & - \\
\hline 1981 & - & - & \\
\hline 1986 & + & & \\
\hline 1989 & - & & \\
\hline 1990 & + & & + \\
\hline 1992 & & - & \\
\hline 1994 & + & & \\
\hline 1996 & - & - & \\
\hline 1998 & - & & \\
\hline 2002 & + & & \\
\hline & & & \\
\hline 197 \\
\hline 1957
\end{tabular}

Table 2. Signature years (+ positive years; - negative years) in oak chronologies: OMS, D10, and D13. Negative years for the Western Pomeranian oaks marked light grey; positive years marked dark grey.

cies may be a high summer temperature resulting in excessive evapotranspiration and water deficiency.

\section{Response function analysis}

The response function analysis described the tree-ring width/climate relationships (Fig. 6) which were very similar to those described for the signature years. The high coefficients of determination (particularly for the downy oak: OMS $\mathrm{r}^{2}=79 \%$, but also for the indigenous oak species: D10 $\mathrm{r}^{2}=50 \%$ and D $13 \mathrm{r}^{2}=55 \%$ ) demonstrated a very strong relationship between tree-ring width and meteorological conditions. $T$ correlation and regression coefficients were higher and more frequently significant for precipitation, than for temperature. In addition, they were positive, which means that high sums of precipitation in different months corresponded to wide tree rings. At all sites October and December of the year preceding the growing period and April of the current period were of influence; the relationships were extremely strong in February and June with respect to both correlation and regression. The coefficients for temperature were usually negative, particularly for July and August of the preceding year (at all sites) as well as for May and July of the actual growth year.

\section{DISCUSSION AND CONCLUSIONS}

In the Bielinek Reserve the downy oaks studied are approximately of the same age as the two indigenous oak species. Contrary to previous estimates of about 100 years (Rezerwat..., 2000), the trees are older than 200 years. The chronologies reconstructed for the native oaks and for the downy oak are very similar, as are changes in the tree-ring widths, which demonstrates identical responses to the changing meteorological conditions. The tree-ring width of Quercus pubescens depends mainly on the magnitude of atmospheric precipitation. A high annual sum of precipitation, particularly a copious rainfall in spring-summer, results in wider annual rings. Springsummer droughts coupled with high air temperatures depress the tree ring growth. Moreover, the amount of snowfall and the duration of snow cover are additional factors affecting the tree-ring width of the oaks growing on the Odra valley slopes studied. A snow cover on south-facing slopes insulates the ground and prevents its heating; water from the melting snow supplies moisture to the roots. Winter rainfalls, too, enhance tree ring width by elevating the groundwater level and increasing the habitat's water supply in spring. The relationships between tree-ring width and climate for the indigenous oak species proved very similar, but the growth responses displayed by Quercus pubescens are more distinct and show a higher statistical significance.

The co-occurrence of the downy oak with other xenothermic species typical of the Mediterranean region as well as results of the dendrochronological and dendroclimatological analyses suggest the natural origins of the downy oak's site at Bielinek.

Polish literature features a discussion on the origin of downy oak in Poland. Some authors (Czubiński, 1950; Celiński and Filipek, 1958; Rezerwat..., 2000) favour the hypothesis of a natural origin of the LithospermoQuercetum subboreale community as a result of an early holocene migration of the xenothermic component and the relict nature of the site. Others (Schwarz 1937, in Celiński and Filipek, 1958 p. 10; Boratyński, 1995; Baryła, 2001) invoke a possibility of the downy oak being introduced accidentally (e.g. in Middle Ages acorns were used as fodder for farm animals), or purposefully (e.g. by Cistercian monks as wood for wine barrels; wine was produced by the monks on the gentler slopes of the Odra valley). However, the absence of any written evidence preclude a verification of either hypothesis.

Downy oaks occurring in Moravia (a location closest to the study site) within the continuous range of the species, grow in very similar habitats, i.e. on steep slopes facing south, with calcium carbonate-rich soil (Chytry, 1997a, b). Aggregations of downy oak (frequently in the form of shrubs) co-occur there - like in Bielinek - with the sessile oak. They are also accompanied by numerous species of plants typical of the Mediterranean region (Chytry, 1997a, b).

A tree-ring width/climate relationship was explored also in downy oak in dry Alpine valleys (e.g., the Valais region in Switzerland), characterised by major climatic factors similar to those in Bielinek Natural Reserve (mean annual temperature $8.6^{\circ} \mathrm{C}$; sum of annual precipi- 

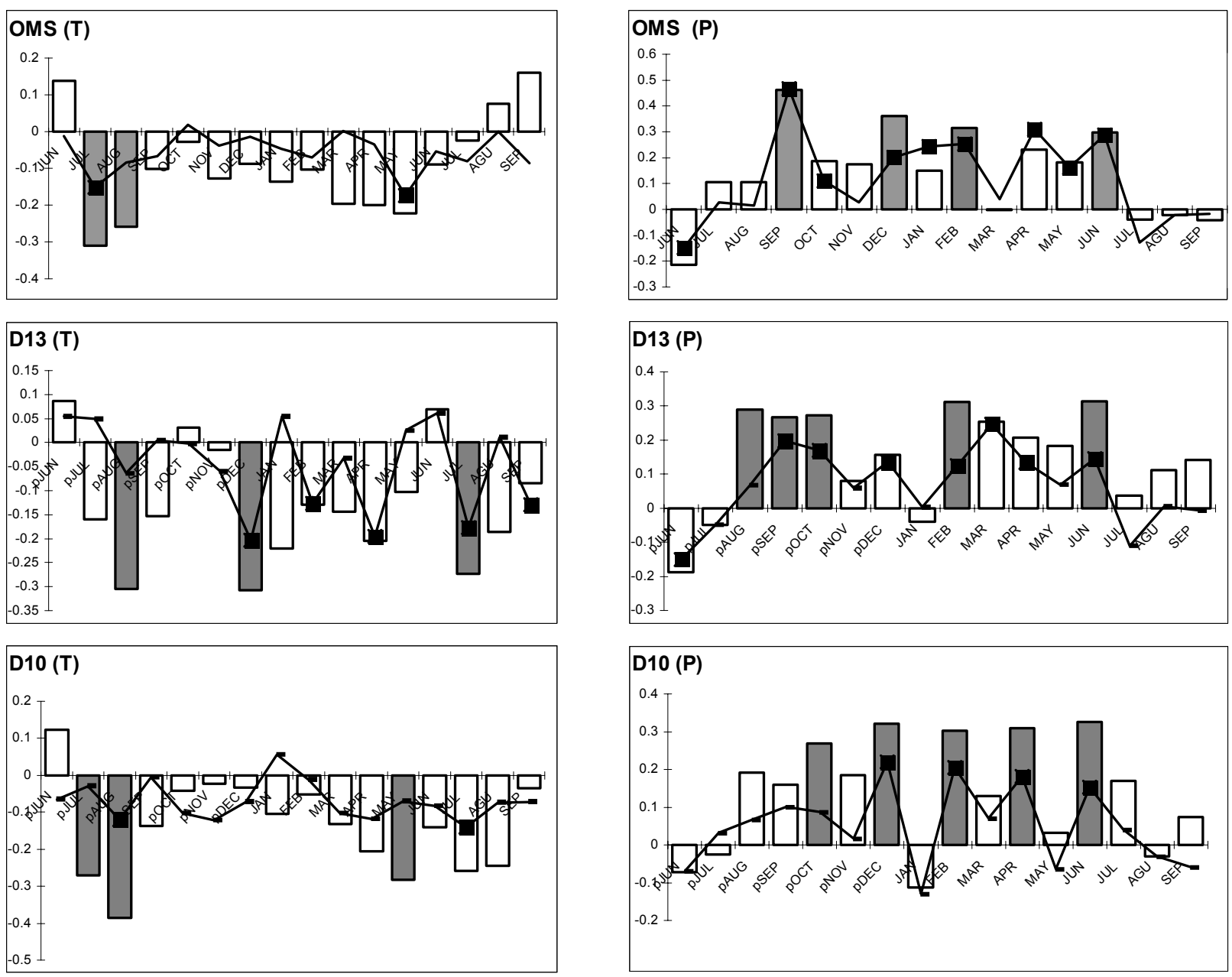

Fig. 6. Response function analysis for $T$, air temperature, and $P$, precipitation. Bars depict correlation coefficients; lines show regression coefficients; significant values are indicated by grey bars and solid black squares. Coefficients of determination: OMS $r^{2}=79 \% ; D 13 r^{2}=55 \% ; D 10 r^{2}=50 \%$.

tation $599 \mathrm{~mm}$; summer precipitation $123 \mathrm{~mm}$; Weber et al., 2005; Eilmann et al., 2006). The thirteen chronologies were 42-109 years long; the climatic conditions were summarised as a moisture index (Ppot) reflecting water availability in the soil and calculated as a difference between the sum of precipitation and potential evapotranspiration (Weber et al., 2005). The downy oak was found to be highly sensitive to variable meteorological conditions, particularly to moisture deficiency in the soil. Positive relationships were revealed for autumn (AugustSeptember) of the year preceding the growing season, and for spring (March-June, with a maximum in April) of that year (Weber et al., 2005; Eilmann et al., 2006).

\section{ACKNOWLEDGEMENTS}

I wish to thank Dr Maciej Trzeciak, the Province Nature Conservation officer, for consent to conduct the study in the Bielinek Reserve; thanks are also due to Dr Bożena Prajs and staff members of the Chojna Forest Inspectorate for their assistance in field work.

The study was supported by the Polish Committee for Scientific Research grant No 2PO4E01027.

\section{REFERENCES}

Baryła J, 2001. Quercus pubescens Willd. In: Polska czerwona księga roślin (The Polish Red Book of Plants): 84-85 (in Polish).

Blasing TJ, Solomon AM and Duvick DN, 1984. Response functions revisited. Tree-Ring Bulletin 44: 1-15.

Boratyński A, 1994. Zarys systematyki dębów (An outline of oak systematics). Sylwan, 10: 73-88 (in Polish).

Boratyński A, 1995. Podstawy systematyki dębów. Quercus, Wydanie specjalne z okazji otwarcia wystawy „Dąb” (Fundamentals of oak systematics. Quercus. A special volume on the occasion of "Oak" exhibition). Ośrodek Kultury Leśnej, Gołuchów: 27-37 (in Polish).

Cedro A, 2004. Zmiany klimatyczne na Pomorzu Zachodnim w świetle analizy przyrostów rocznych sosny zwyczajnej, daglezji zielonej $i$ rodzimych gatunków dębów (Climatic changes in Western Pomerania in the light of analysis of tree-ring sequences of Scots Pine, Douglas Fir and native species of Oak). Wydawnictwo In Plus. Szczecin: 30-36; 51-58 (in Polish, with English summary).

Cedro A, in press. Dendrochronologiczna analiza sekwencji przyrostów rocznych dębu omszonego występującego na jedynym stanowisku w Polsce w Rezerwacie „Bielinek” w porównaniu do kształtowania się słojów przyrostu rocznego u rodzimych gatunków dębów (Dendrochronological analysis of tree-ring sequence of downy oak at its sole site in Pland, in the Bielinek Reserve, in relation to radial increment development in indigenous oak species) (in Polish).

Celiński F, and Filipek M, 1958. Flora i zespoły roślinne leśnostepowego rezerwatu $\mathrm{w}$ Bielinku nad Odrą (The flora and plant communities of the forest-steppe reserve in Bielinek on the Oder). 
Badania fizjograficzne nad Polska Zachodnia IV: 5-198 (in Polish, with English summary).

Chytry M, 1997a. Plant communities of the thermophilous oak forests in Moravia. Preslia 68: 193-240.

Chytry M, 1997b. Thermophilous oak forests in the Czech Republic: syntaxonomical revision of the Quercetalia pubescenti-petraeae. Folia Geobotanica Phytotax. 32: 221-258.

Ciaciura M, 1997a. Przewodnik po rezerwacie przyrody „Bielinek” (A guide to the Bielinek Natural Reserve). Wojewódzki Konserwator Przyrody w Szczecinie: 2-23 (in Polish, with English summary).

Ciaciura M, 1997b. Historia badań florystycznych w rezerwacie leśnostepowym „Bielinek” nad Odrą w okresie od 1945 r. do 1997 r. Materiały z sesji okolicznościowej poświęconej obchodom 70-lecia powolania rezerwatu przyrody „, Bielinek” (History of floristic research in the Bielinek on the Odra forest-steppe reserve in 19451997. In: Proceedings of a special session commemorating the $70^{\text {th }}$ anniversary of the Bielinek Nature Reserve): 11-26 (in Polish).

Cook ER and Kairiukstis LA, 1990. Methods of dendrochronology; chapter 3, Data analysis. Kluwer Academic Publishers: 97-162.

Czubiński Z, 1950. Zagadnienia geobotaniczne Pomorza (Geobotanical problems of Pomerania). Badania fizjograficzne nad Polska Zachodnia (2) 4: 498-517 (in Polish).

Eilmann B, Weber P, Rigling A and Eckstein D, 2006. Growth reaction to drought years of Pinus sylvestris L. and Quercus pubescens Willd. on a dry site in the Valais, Switzerland. Dendrochronologia 23: 121-132.

Fritts HC, 1976. Tree rings and climate. Academic Press, London-New York-San Francisco, 567 pp.

Fritts HC and Xiangding W, 1986. A comparison between responsefunction analysis and other regression techniques. Tree-Ring Bulletin 46: 31-46.

Holmes RJ, 1983. Computer-assisted quality control in tree-ring dating and measurement. Tree-Ring Bulletin 43: 69-78.

Holmes RJ, 1994. Dendrochronology Program Library. Users Manual. University of Arizona, Tucson.

Huber B, Giertz-Siebenlist V, 1969. Unsere tausendjahrige EichenJahrringchronologie, durchschnittlich 57 (10-150) - flach belegt. Sitzungsbericht der Osterreichischen Akademie der Wissenschaften, Mathem.-naturw. Kl., Abt. I 178: 37-42.

Kaennel M and Schweingruber FH, 1995. Multilingual Glossary of Dendrochronology. WSL FNP, Haupt: 467pp.

Krawczyk A, 1995. Program komputerowy TREE RINGS (TREE RINGS Computer software). Kraków.

Krawczyk A and Krapiec M, 1995. Dendrochronologiczna baza danych. Materiaty II Krajowej Konferencji: Komputerowe wspomaganie badań naukowych (Dendrochronological data base. Proceedings of the Polish Conference on Computer Assistance to Scientific Research). Wrocław: 247-252 (in Polish).

Mindur B, 2000. Dendrometer 1,0 (Dendrometer 1.0 Software). Kraków.

Schwarz O, 1937. Monographie der Eichen Europas und des Mittelmeergebietes. Repertorium specierum novarum regni vegetabilis, Sonderbeiheft D. Berlin-Dahlem: 200pp.

Staszkiewicz J, 1977. Pozycja systematyczna dębu omszonego (Quercus pubescens Willd.) z rezerwatu leśno-stepowego w Bielinku nad Odrą w oparciu o analizę biometryczna liści (Taxonomic status of the downy oak (Quercus pubescens Willd.) in the forest-steppe reserve at Bielinek on the Odra, as elucidated by biometric analysis of leaves). Fragmenta floristica et geobotanica XXIII, 3-4: 259-276 (in Polish, with French summary).

Sukopp H, 1997. Historia powstania rezerwatu przyrody "Bielinek" jego naukowa eksploracja do roku 1945. (Origins of the Bielinek reserve and its scientific exploration prior to 1945). Materiaty z sesji okolicznościowej poświęconej obchodom 70-lecia powołania rezerwatu przyrody „Bielinek” (Origins of the Bielinek reserve and its scientific exploration prior to 1945). In: Proceedings of a Special Session Commemorating the $70^{\text {th }}$ Anniversary of the Bielinek Nature Reserve): 8-10 (in Polish)

Rezerwat Przyrody "Bielinek", 2000. Plan ochrony na okres od 01.01.2000 r. Do 31.12.2019 r. (Bielinek Nature Reserve. Conservation Plan for 1 January 2000 - 31 December 2019). Operat, Toruń: 175pp (in Polish).

Walanus A., 2001: DendroGraph - program druku krzywych grubości słojów przyrostów rocznych. Instrukcja obstugi programu DendroGraph (DendroGraph - a software for plotting tree ring width curves. DendroGraph Software User's Manual). Kraków (in Polish): $6 \mathrm{pp}$

Walanus A, 2002. Instrukcja obstugi programu TCS. Program TCS do obliczania lat wskaźnikowych (User's manual of TCS software. TCS software for calculation of signature years). Kraków: 6pp (in Polish).

Weber P, Rigling A and Bugmann H, 2005. Differences in drought response of Pinus sylvestris L. and Quercus pubescens Willd. in the Swiss Rhône valley. In: Jansma E, Bräuning A, Gärtner $\mathrm{H}$ and Schleser, G, eds, TRACE. Volume 2. Proceedings of the Dendrosymposium 2004. Schriften des Forschungszentrum Jülich, Jülich 3: $48-52$.

Zielski A and Krapiec M, 2004. Dendrochronologia (Dendrochronology). PWN Warszawa: 328pp (in Polish). 